\title{
INSTITUTIONAL ASPECTS OF EUROPEAN ECONOMIC POLICY COORDINATION MECHANISMS: THE IMPLICATION FOR SERBIA*
}

\author{
Marko Dimitrijević, PhD, Assistant Professor \\ University of Niš, Faculty of Law \\ 18000 Niš, The Republic of Serbia \\ markod1985@prafak.ni.ac.rs
}

\begin{abstract}
The subject of analysis in this paper is to review the institutional aspects of coordination mechanisms for economic policy in the European Union. In this context, the first part of the article defines the concept of coordination, the benefits versus the competition, the goals and the principles on which mechanisms are placed. In the second part of paper points to the impact of the mechanism for coordination of economic policy in Serbia, costs and benefits of the coordination process, i.e. primarily in the light of the new wave of coordination which started with the new model of economic governance during the global crisis embodied in the provisions of the European semester, the European Stabilisation Mechanism and the Treaty on Stability, Coordination and Governance in the Economic and Monetary Union. The central hypothesis is based on the fact that Serbia its economic policy must shape according to European coordination mechanisms in the broadest sense, and not only in the field of monetary and fiscal policy, but also other segments of structural macroeconomic policies (labour market, as well as in the new areas such as environmental policy and cohesion policy) to achieve sustainable economic development. Although the domestic economic policymakers have done a lot on that plan, there is still a practical and logical need for the harmonisation of specific segments of economic policy and reducing the time lag in the implementation of the actions of economic policy.
\end{abstract}

Keywords: Coordination, Economic Policy, EU, New Economic Governance, Serbia

The paper is a result of funding from the Ministry of Science, Education and Technological Development of the RS under contract number 451-03-68/2020-14/200120 


\section{INTRODUCTION}

The success or failure of the European economic and monetary union in achieving macroeconomic objectives of the Community is conditioned by the fact that the Member States centralised monetary policy. In contrast, the differences in the concept of managing fiscal policy of labour are continued to be very strong. The reason why the Member States did not want to limit its fiscal and financial sovereignty (subjective budgetary law) is reflected in the fact that as "supreme power over the money," a constitutive element of political sovereignty of each country. In the economic literature, it points out that the institutional framework of monetary union relatively successfully installed, and the main problem of relative success in achieving price stabilisation and economic growth is the decentralised economic policy. ${ }^{1}$ The existence of a single monetary policy that is governed by the provisions of communitarian law and decentralised fiscal and structural policies regulated by the rules of national law makes the question of coordination significant for both, in theory, and the practice of European Union law. Although the need for coordination of economic policies of member states took a special place in the Rome Treaty, only by the adoption of the Maastricht Treaty the process of coordination at a higher level is institutionalised (art. 99). Also, this legal act establishes a duty to make guidelines for economic policy coordination by the Commission. It is interesting to point out that despite the frequent use of the term coordination in the provisions of the primary and secondary law of the European Union, there is no generally accepted definition of this concept. EU institution had played very important role in EMU, but that had changed over time by intergovernmental action as an important principle in economic policy coordination. ${ }^{2}$

\section{THE CONCEPT OF ECONOMIC POLICY COORDINATION}

The concept of coordination of economic policy in its meaning can be multifaceted. The classic definition of which has spoken Wallich coordination sees as "a form of significant restrictions on national policies to recognise the state of global economic interaction between countries". ${ }^{3}$ Although this understanding of coordination often used in the literature, its main drawback is that it does not make a distinction between the limitations that arise as a result of interstate agreements

Lastra, M. R. et al., European Economic and Monetary Union: History, Trends and Prospects, Year Book of European Law, 2013, pp. 1-15

2 Amtenbrink, F.; Hermann, C., The Law of EU Economic and Monetary Union, Oxford University Press, 2020, pp. 787-811

3 Mooslechner, P.; Schuerz, M., International Macroeconomic Policy Coordination: Any Lessons from EMU?, A Selective Survey on Literature, in: Hughes, A. et al. (eds.), Challenges for Economic Policy Coordination within the European Monetary Union, Kluwer Academic Publisher, 2011, pp. 65-90 
from those restrictions are the results of decisions subjects of national law in terms of the functioning of the international factors. To correct such deficiencies of classical definitions, (Web) coordination sees as a "vision of harmonization of national policies in terms of the conduct of multilateral negotiations between states which means that on that occasion, adopted a concept that is significantly different from that concept, which would be the result of independent decisions of contracting parties". ${ }^{4}$ Perhaps the most widely used definition of coordination gives Kenen, who had defined coordination as "the most rigorous forms of economic cooperation among the countries, which mean the exchange of explicit and operational (applicable) obligations in terms of functioning monetary and fiscal policy." As a form of economic cooperation between the states, coordination can have many new ways. In the simplest case, coordination will be reduced to the exchange of information. At the same time, in conditions of economic crisis, it can have an ad hoc character and indicate the measures which are taken to overcome the economic disturbances.

According to the comprehensiveness of the subsystem of economic policy, coordination can occur as a part if it relates to only some of the objectives of economic policy or completes if it comprehensively regulates all the constituent elements of a common economic policy. On the coordination of economic policy can be spoken and in the constitutional, i.e. allocative terms and political terms. ${ }^{5}$ The constitutional (allocative) sense of coordination process is reflected in the single monetary policy as well as the consequences of the single market, to market economies and competition law as well as the fundamental economic framework of the EU. Firm rules of coordination involve a constant search for the elements and regions that will complete the framework of fiscal and financial control in various segments of economic policy in the planning, decision-making, implementation and monitoring of the results. The political aspect of coordination relates to the use of so-called "open method of coordination", which involves labelling the rapper, conducting constructive polemics, dissemination of good practices and exchange of information on different legal mechanisms. These distinctions arise from the difference between economic and financial arrangement. Economic governance is based on principles of a market economy with financially oriented incentives, while the financial management focuses on financial equity and government accountability. By synchronised using, both aspects of coordination at the same time

Webb, M. C., The Political Economy of Policy Coordination-International Adjustments Since 1945, Cornell University Press, 1995, p. 40

5 Henke, K. D., Managing Subsidiarity from an Economic Point of View, Soft Co-ordination and Hard Rules in European Economic Policy, Technische Universitat Berlin, Discussion Paper No. 2, 2006, p. 11 
overcome the disadvantages of failure of markets and governments in approaching the various economic practices of Member States.

Based on the above, we can notice that the very notion of coordination multidisciplinary, since it contains the meaning of the legal, economic and political nature. Coordination is necessary (in our opinion), to observe in the light of supranational norms, accepted by all (most of) the member states, while leaving the competence for managing economic policy at the national level, but with a separate set clear limits by independent (discretionary) decision-making. The objectives which supposed to be pursued through the joint action of the economic policy of the Member States are motivated by political interests. Effective mechanisms for achieving these goals provide national and communitarian legal system, both preventive and repressive way (by sanctions of different nature) arising from the legal acts of different strengths to meet the agreed behaviour of the subjects of economic policy. It is for the reasons above, the question of coordination of economic policy is increasingly attracting the attention of economists and lawyers constitutionalist who are aware of its importance for the achievement of general social well-being.

\subsection{Coordination versus Competition}

Ratio legis of establishing legal mechanisms for coordination of economic policy in the European Union is reflected in the protection of public goods and internalisation of negative external effects. In the conditions of existence of the monetary union led to the emergence of public goods that are in terms of their nature international and transcend the geographic boundaries of one member state. With the development of economic and monetary union, the number of these properties is continuously increasing. These "new" public goods are derived from the existence of the Union's objectives and relate to the better integration of the market, reducing the economic costs, the free movement of capital, people, goods, services, the single market and the existence of the customs union. ${ }^{6}$ Taking into account the fact that all countries are not the members of Union, at the same time and the members of the eurozone, there is a real danger that these countries act as so-called "free riders". In the absence of legal mechanisms for coordination of the entire member states which establishing clear obligations, the countries "non-members" of monetary union, hypothetically speaking, can enjoy the benefits arising from the public properties such as the single monetary policy, i.e. monetary stability without paying their costs. About the theory of public finance as the main characteristics of public properties cited the absence of rivalry and non-excludability

Collignon, S., Economic Policy Coordination in EMU: Institutional and Political Requirements, Harvard University Center for European Studies, 2001, p. 37 
in use, and the question is how to regulate the position of non-member states of the monetary union?

The external effects in terms of its nature and consequences caused in practice can be very diverse. Depending on what you designate as criterium divisions (lat.), in theory, it can make different classifications. So it can make a distinction between internal and external spill-over effects. ${ }^{7}$ External spill-over effects occur in the relations of the eurozone with the rest of the world. So, for example, changes in world trade and economy of the United States affecting economic ties in the European Union and the ratio of the exchange rate of the euro and the dollar. Oil prices in other raw materials are determined on the international market beyond the control of the eurozone but have a substantial impact on the economies of member countries. Internal effects of spill-over occur as a result of uncoordinated structural reforms of the Member States. When reforms (which are aimed at increasing competitiveness) are not implementing the synchronised legal tools and instruments in all Member States (but only in one or a few countries) may be called "race to the bottom". ${ }^{8}$ Depending on whether these effects are in a function of acceleration or deceleration of economic activity, it can make the difference between positive and negative effects. Positive effects are, as we have already pointed out, the preferred because they encourage the development of the economies of other countries. Negative effects, on the other hand, are the result of inconsistent and mutually conflicting actions of economic policies of member states. In the case of negative effects, there is a real and logical need for monitoring of the situation, by the formation of corrective mechanisms (which determines the legal remedies for the violation of economic equilibrium) and sanctions for non-compliance the rules of conduct. We must note that such a clear distinction between the external effects can be made only in theory. In practice, the characteristics of these effects are often intertwined with each other. Still, they cannot always be determined with certainty what form belongs to the external effect in a concrete case. Interconnection effects and their complexity can mean overestimation or the underestimation of concrete effect. Therefore, coordination mechanisms are not perfect and often have gaps that must be solved subsequently. At the level of the European Union, the effects become negative if the individual countries formed the concept of economic policy contrary to the principles of credibility, not taking into account the consequences of their measures and instruments on the situation in the economies of other countries. For this reason, we believe that national entities of economic

Aarle, V.B.; Weierstrass, K.; Schoors, K., Economic Spillovers, Structural Reforms and Policy Coordination in the Euro Area, Springer, Munich, 2006, pp. 39-41

8 A typical example of such behaviour is unfair (harmful) tax competition which the only purpose is the deliberate diversion of investments in one country 
policy must treat bona fides (lat.). Following the legal standard of "good businessman" when creating and managing a programme of economic policy, otherwise, it can lead to severe macroeconomic imbalances which are due to the effects of the multiplication of EMU challenging to solve.

Some authors point out that public properties that are created by the creation of European monetary union have the character of specific categories of public properties, the so-called "club properties" on which users have rights only states which accept certain rules of conduct. ${ }^{9}$ These rules include the implementation of legal and economic convergence criteria that must be met for accession to the euro-zone. In terms of the monetary union, macroeconomic variables such as exchange rates, interest rates and the amount of the price gain are getting much greater importance than in the conditions of the independent monetary policy. In the literature, as the classic examples of negative external effects allegations are cited implications of aggressive wages policy and nonconforming fiscal policy. The process of coordination for sure gets its justification in situations where high public debt in a country seen as a threat to price stability in the euro-zone, making the exchange rate may rise due to higher risk premiums (which mean a depreciation of the euro). In the area of wage policies, lack of coordination could mean that if wages rise in one country, there is an increase in inflation and a potential reduction in the value of the euro, which is why the European Central Bank must decide on increasing the interest rates.

In the case of irresponsible conduct of their economic policies, Member States may produce costs to other countries, which are reflected in the cost of inflation, in the amount of income and changes in public spending, as the question of coordination of economic policy makes necessary. ${ }^{10}$ By the coordination of economic policy, it can prevent the occurrence of adverse effects or at least minimize their legal-economic and political impact on the economy of the countries of the Union. Off course, the condition is that there are legal mechanisms which apply erga omnes (lat.) to all members, regardless of whether they belong to a group of economically and politically most influential states or not. If the coordination mechanism set up in the function of "pareto efficiency", it becomes an instrument for achieving general social well-being. ${ }^{11}$

9 Schiede, J., Macroeconomic Policy Coordination in Europe-An Agnostic View, Kiel Institute for World Economics, Kiel Working Papers, No. 1174, 2003, pp. 10-11

10 Wyplosz, C.; Baldwin, R., Economics of European Integration, McGraw-Hill Higher Education, 2012, p. 111.

11 Colignon, op.cit, note 6, p. 12 


\subsection{The Objectives of Economic Policy Coordination}

The main objective of economic policy coordination is the harmonisation of macroeconomic policies within the European Union. This objective seeks to achieve a variety of instruments and measures that should the conduct of fiscal and other policies of the Union make complementary and consistent with the objectives of the European Central Bank. To fulfil this mentioned goal, it is necessary to point out the two biggest dilemmas in this area: the problem of social cost and the problem of collective action. ${ }^{12}$ The problem of social cost is conditioning the effects of the objectives of coordination. Thus, suggests that if the conditions of the open economy, there is a free exchange rate, the government budget deficit can cause crowding out domestic private investors by increasing the height of the exchange rate of the domestic currency. The consequences are reflected in the reduction in aggregate demand caused by the depreciation of the domestic currency for monetary tightening. In terms of the existence of a free exchange rate, fiscal policy coordination becomes unnecessary about the level of EMU there is no single established a fixed exchange rate. In such circumstances, the state which is facing a budget deficit will not have a problem with a high exchange rate, because the effect of crowding out is transferred to the entire eurozone and occurs in the form of higher interest rates. The problem of collective actions in the general coordination of economic policy relates to the credibility of monetary policy which in EMU receives the characteristics of public properties. When credibility is establishing in the full sense of the word none of the Member States of the Union will not be able to exclude other from the benefit, such as price stability and lower costs of inflation. However, there is a fear of a large number of countries that behave like free-riders may cause the collapse of the credibility of the work of the European Central Bank. The behaviour of free riders is reflected in the utilisation of benefits arising from the prudent management of public finances conscientious member states, which respect the rules of fiscal and financial convergence established by the Treaty of Maastricht. In terms of the existence of the global economic and financial crisis, it seems that the credibility is threatened more than ever since the establishment of EMU, as the European Central Bank is under a lot of pressure member states. Relativisation of provisions of non-funding the public debt of the Member States (no-bailout clause), the formation of the European Stability Mechanism and the decisions of the European Court of Justice on (not)violation of the basic principles of monetary union in favour of this fact.

12 Begg, I.; Hodson, D.; Maher, I., Economic Policy Coordination In the European Union, National Institute Economic Review, no. 183, 2003, pp. 66-77 


\section{THE BENEFITS AND COSTS OF ECONOMIC POLICY COORDINATION}

Before you begin any research on the topic of preferences and the lack of the concept itself, format and coordination mechanisms are necessary to determine whether the object itself of coordination can be better achieved through market processes that are far from political influences (see Henke 2006). Thus, points out that the market provides a kind of strong coordination through the market rules and the application of the principle of subsidiary. Although the market economy remains the most optimal coordination principle, it is in initiatives of the Commission's for the strengthening of the process often neglected. Supporters of principle claim that the reason for such Commission behaviour is in the postulates of the theory of bureaucracy. Namely, in contrast to economic integration in which there is a control, and political integration in which such a mechanism is missing,principal-agent problem provides the agents(the Commission) to use the process to strengthen their authority against the interests principals (states). We believe that such a radical observation of the role and importance of the work of the Commission in the coordination process is unacceptable because it is the efforts of the Commission that process of coordination in economic policy became a matter of public interest when due to market imperfections the harmonisation of national policies cannot be achieved. The application of the mechanisms of coordination of economic policy in the European Union is not free. It produces certain effects in practice, which can be characterised as positive (benefits) and as negative (costs). By comparing the costs and benefits, we can identify elements of the optimal concept of coordination in terms of its objectives, instruments, the scope of coverage, the field of application, the institutional framework and legal justification. The benefits of economic policy coordination mechanisms are primarily reflected in the realisation of the idea of a single Union market in the full sense of the word, in accelerating technical progress and deepening the values of economic and monetary union. Although it seems that in terms of the benefits of coordination mechanisms, no significant concerns, Feldstein in his recent works, examine their actual dimension. In this light, he considers that one cannot speak about the benefits of coordination of economic policy in the euro-zone when it does not exist. Particularly emphasised that the introduction of the single curren$\mathrm{cy}$, in an area where there is no adequate geographical mobility of capital and fiscal structure, economically is an inefficient solution. Also, he argues that the issue of coordination cannot be identified with the delegation of monetary sovereignty to 
the level of communitarian law because it is just a transfer of economic policy, not its coordination. ${ }^{13}$

When designing the concept of coordination, in our opinion, it is essential that entities are set up in the role of the legislator and to act with due care, so that they provide a higher degree of all the circumstances that there is the coordination instruments include a need in the coming periods. The concept of coordination at the time of preparation cannot cover all aspects of economic policy (which is necessary to regulate the legal norm due to the dynamism of legal-economic relations and limited rationality of economic policy subjects). Because of that, some minor or major revisions are necessary. Circumstances that affect the success of coordination are conditioned by the existence of invariability and uncertainty, which should be limited as much as possible. ${ }^{14}$

Variability can reduce the degree of success of coordination if the subjects of economic policy do not comply with pre-agreed rules and standards, which implies that the programmes must be created to achieve not only national interests but also to achieve the common interests of the Union. If behind the concept of coordination are not supranational entity law, the concept itself will be counterproductive and will not generate the said benefits to the Member States. Deviations of the State members in advance of the agreed objectives and instruments determined by institutional arrangements of coordination without adequate sanctions from the norms of communitarian law, imposing the need for stricter rules. If such regulations were in a function of price stabilisation and stable interest rates, we believe that the rules in it in addition to the disposition which explains the specific obligation of the State Union must necessarily contain an effective legal sanction. All countries which participate in the coordination process must inevitably work to create an institutional environment in which there are real conditions for the imposition and implementation of credible sanctions.

Uncertainties about determining and measuring the effects of externalities and spillover effects may also thwart the benefits of coordination. In this sense, macroeconomic models that identify external effects can be very different from each other. The degree of uncertainty (that is, in a certain sense always present) can be reduced in a socially tolerable level if design concept of coordination in addition to the governments of the Member States of the Union, participating as many independent experts and scientists who possess specialised knowledge in the field of

13 Feldstein, M., Coordination in the European Union, Working Paper No 18672, The National Bureau of Economic Research, 2013, pp. 1-10

14 Mooslechner; Schuerz, op.cit, note 3, p. 49 
legal and economic sciences. Once again, we note that it is essential that they act according to the rules of the profession (de lege artis) and not guided by national political interests of their governments. How, in our opinion, this requirement is difficult to achieve in bureaucratic world "key to success" of coordination is conditioned by intensive engagement of scientists and experts in the said process.

In examining the benefits of coordination, an important determinant represents the circumstances that are related to the existence of uncertainty and variability, provided that their resolution is a necessary but not sufficient condition to generate significant benefits in the euro-zone. In support of the aforesaid, Webb in his polemics about the coordination benefits asserted that its success is mainly caused by the allocation burden method that adjusting the national legislation to the Union. That existence of the fear for the application of sanctions for noncompliance with commitments remains only just a secondary factor of nature. ${ }^{15}$ The costs of coordination of economic policy were the subject of discussion of many economists. It is believed that the highest cost of coordination in reducing the level of competitiveness between countries. Also, the literature points out that the costs are deepened in terms of economic policy coordination because it is an action which in the case of the EU are determined to communitarian level with the sign of supremacy over the domestic law. As the objectives and measures of coordination can be identified practically, is likely to define and wrong, but the member countries will have to no matter that to imply inevitably. Such potential mistakes lead to the sort of cascade effect that threatens to significantly slow down the process of coordination or repudiate the results achieved, if not timely detected and correct deficiencies. The impediments that increase the costs of coordination are relating to the number of entities that access to monetary union and the existence of certain legal restrictions. Coordination costs are directly conditioned by negotiating of Member States. Taking into account the tendency of membership increasing, which is inevitable due to the expansion of the EU, the question is whether such compromises possible? If possible, we rephrase the question in a way, how much time is required to elapse before the completion of the agreement begins to produce the desired legal effect? The synchronisation of different preferences works particularly challenging in some segments of fiscal policy. For example, in Germany, the central bank does not have the authority to decide on changes in the conduct of fiscal policy independently. Experiences show that even in circumstances where it is clear that such changes lead to increased social welfare (e.g. the elimination of subsidies), is challenging to conclude agreements, which

Webb, op. cit., note 40 
may discourage attempts to coordinate tax policies. ${ }^{16}$ This problem becomes more complicated if it is added to the issue of coordinating the wages policy.

Legal restrictions are theoretically related to the role of the European Central Bank out of coordination of monetary policy, in the area of fiscal policy and other macro-economic policies. As the jurisdiction of the ECB clearly defined by the provisions of primary law, the question is whether the implicit city expansion of jurisdiction. As the European Central Bank must maintain relations with other subjects of the Union, it is crucial to determine the legal effect of agreements and joint statements. In official documents of the EU is taken a stance that all agreements of ECB and other institutions, legally optional and cannot, under any circumstances take the form of ex-ante coordination. ${ }^{17}$ In terms of the global economic and financial crisis, this problem becomes especially important, because it raises the question of whether the scope of the jurisdiction of the leading EU institutions should be reviewed. In this regard, it seems that in a crisis can get to a justified deviation from the principle of non leges potens pertinent (no more than allocated rights), if it is warranted to achieve the common good, and in the preservation of order in the monetary sphere.

In considering the costs and benefits of coordination, we must take into account the effect of the time lag in the implementation of measures and instruments of economic policy, which under conditions of economic and monetary union obtaining a complex dimension. In this regard, a distinction is made between the inner and outer lag. ${ }^{18}$ Domestic delay covers the period from the moment when it is necessary to take action until the moment of enforcement measures. Outer lag is a period which elapses between the moment of action taken and the moment of its effects in the economy. The inner lag occurs in recognition lag, deciding what action (decision lag), and in the course of the action (action lag). The lagging in recognising the disorder at the Community level is a significant challenge, because, as a rule, it takes the most time, regardless of whether it comes to disturbances in the monetary and fiscal sphere. When it comes to decision-making lag in the field of monetary policy, it must be borne in mind that the European Central Bank makes all decisions. In contrast, in the area of fiscal policy, the decisions are made by the national fiscal authorities. The European Central Bank, in many cases, the decisions are made quickly and efficiently. At the same time, the process of decision-making by governments can be prolonged (especially when it

\footnotetext{
16 Schiede, op. cit., note 9

17 European Central Bank, The ECB's Relation with Institutions and Bodies of the European Community, Monthly Bulletin, 2004

18 Vukadin, E., Economic Policy, Faculty of Law, Belgrade, 2009, pp. 38-39
} 
comes to adopting new or amending existing budget laws, tax laws and the law on public debt). Lagging in terms of applications is a challenge that needs to be systematically addressed, because the effects of the use of monetary policy measures are quickly noticed, but not from the implementation of fiscal policy in which at that time is potentially longer. How effective coordination mechanism prejudge the simultaneous use of measures of centralised monetary policy and decentralised fiscal policy, the time delay may affect the final result of the coordination process, due to which the subjects of economic policy must make further efforts to shorten the time horizon of the mentioned periods.

\section{THE PRINCIPLES OF COORDINATION MECHANISMS}

The ratio of internal and communitarian law is a decisive factor in shaping a transparent, efficient and legally justifiable concept of the economic policy of coordination in the EU. By the Maastricht Treaty is introduced the principle of subsidiarity, which is the proper understanding and application condition sine qua non (lat.) of political and financial stability in the Union. As we have previously noted, this principle has been established that "Community operating in areas which do not fall within its exclusive competence only to the extent and only if the Member States are not efficient enough to achieve the goals that need to be implemented based on the proposed measures and, therefore, based on the arguments which are concerning the scope and intensity of the impact of the proposed measures, can better be achieved at a Community level " (Maastricht Treaty, art. 5). The Treaty of Amsterdam supplements this principle by the principle of proportionality, which stipulates that" the Community will not go beyond the steps that are necessary to realise the objectives. "We note that the principle of speciality and proportionality limits the application of the principle of subsidiarity. According to the principle of speciality follows that the Community acts within its jurisdiction. In contrast, the principle of proportionality restricts that its actions will not go beyond the necessary framework to achieve an objective. The formulation of subsidiarity is a crucial concept because it is interpreted in analogy with economies of scale and externalities. ${ }^{19}$

In the broadest sense, this principle means that decisions should be made at the level closest to the citizens. So, the Union should not take any action if it does not mean that such an operation to be more effective and that measures should be taken at the national, regional or local level. The principle of subsidiarity can be considered an element of the principle of fiscal federalism. Under this jurisdiction, the country should not be delegated to lower levels of government or to raise

19 Prokopijević, M., The European Union-Introduction, Belgrade, 2009, pp.110-111 
to a higher level, compared to the one on which jurisdiction can be efficiently carried out. The problem with its interpretation depending on the preferences of interpreters under its content may fall within intensive interpretation or can get a pervasive interpretation. According to the broadest interpretation of the principle of subsidiarity, its application can include everything that is on the level of the Community that can be effectively implemented. The rule is that the burden of proof borne by the person who proposes actions to be taken at the Community level (actori in cumbit probatio). In this role could be found, Member States or EU bodies. Of course, in practice, it is mentioned that proving is difficult to implement because it determines the domain of political agreements, the terms and conditions of application of the principle itself. The problem with its interpretation, according to some understandings, reflected in the fact that the principle hiding his true nature, and the ability for continuous expansion and centralisation of power of the EU institutions. However, the legislative intention was that the level of communitarian law does not exercise too much influence. History Integration, in this sense, clearly shows the continuous expansion of jurisdiction, which reached its top in the creation of the single currency and the establishment of the European Central Bank.

The application of this principle in practice further complicates its substantive ambiguity, both legal and in economic terms. Economically speaking, this principle is often identified with the institutional manifestation of the general principle of comparative advantage. ${ }^{20}$ That would mean that its use is characteristic of countries where there is a clear division of labour and specialisation, which means that within the community for exercising specific goals are competent those units that make them in the most effective way to be achieved concerning other units. As such, the principle becomes a characteristic of the countries with open economies, which include member countries of the EMU. At this point, we cannot, and do not ask the question whether is insufficient precisely a legally-economic meaning of the term, one of the factors of contradictory results so far in the general coordination of monetary and fiscal policy in the euro-zone, because it is the correct interpretation of legal norms (principles) of the same condition for the effective implementation of the legal communication? The existence of different "standards and techniques" of interpretations which are based on different economic positions of the Member States and political influence, impose the need to establish uniformity in the application of the principles of subsidiarity. The legal doctrine is advocating the application of different mechanisms through which it can improve the implementation of the principle of subsidiarity in the field of economic policy.

20 Schäfer, W., Harmonization and Centralization Versus Subsidiarity: Which Should Apply Where?, Intereconomics, vol. 45, no. 1, 2006, pp. 246-249 
The rhetorical questioning in connection with the distribution of competences in the field of monetary and fiscal policy can be reduced by applying the so-called "functional subsidiarity test. ${ }^{21}$ The application of this test involves the application of four successive steps. The first step involves the identification of areas in which the measures and the instruments have not been satisfactory. If it is an area which falls under the exclusive competence of the Community, the test is abandoned, but it should be noted that this step. However, an initial may be required for the application because the Maastricht Treaty is very complex. The second step means the application of criteria externalities, economies of scale or other principles. If the Member States voluntarily cooperate on solving a specific problem, there is no need for the intervention of supranational levels of government, provided that the cooperation is authentic. In the third step, it is necessary to check whether there are conditions that such cooperation remains an authentic pro future (lat.) or not, due to exposure to different political interests and turmoil. In the fourth step, if we conclude that the first and second step is met, and the third did not, the competence belonging to the Community. If there are a sufficient number of conditions for credible cross-country coordination, the Community does not have to intervene. Therefore the competence remains at the national level of government. Alternative ways of solving the application lack imply the creation of specific mechanisms of so-called "early warning subsidiarity mechanism". ${ }^{22}$ This mechanism takes the form of a new legislative procedure, which foresees the participation of national parliaments in the creation of EU primary law for the first time. More specifically, the national parliaments would symbolically speak, put in the role of principle "watchdog". Such a procedure would allow the representative bodies of the Member States to present all remarks related to the European legislation for which they believe that violates the subsidiarity rule and before the same shall approve or implement.

In considering the principles of coordination, it is necessary that the Court of Justice can determine whether the character of the measures taken at the supranational level justifies its consequences in the legal-economic system of Member States. Indeed, here the proportionality does not occur as a component of subsidiarity. It represents an independent jurisdiction of the Court, in violation of national measurement values to achieve communitarian goals. That seems hard to apply in practice because the Court cannot accept that the Council (or rather representatives of the country of which it is composed) voted on the application

${ }_{21}$ Pelkmans, J., An EU Subsidiarity Test is Indispensable, Intereconomics, vol. 41, no. 5, 2006, pp. 249254

22 Cooper, I., The Subsidiarity Early Mechanism: Make it Work, Intereconomics, vol. 45, no. 5, 2006, pp. 254-257 
of the communitarian dimensions oblivious to the fact that this undermines the supranational value. For this reason, it is difficult to accept that the violation of national values (in terms of economic policy, monetary, fiscal and financial sovereignty) is disproportionate to supranational one. In the coordination process, Member States are required the certain compromises, which some national operators provide, i.e. consuming more or fewer benefits, it is justified for the sake of establishing a functional institutional mechanism that contributes to achieving macroeconomic stability.

Due to the frequent inconsistencies in principle application, theoreticians such as Schafer (2006) proposed the institutionalisation (legalisation) exit from the Member States of those segments of the common policies where there is a severe and frequent breach of the principle. We believe that in an extreme form, leaving the legalisation of values and objectives of the common policies can permanently and irreversibly threaten the already fragile fiscal policy coordination mechanism. Also, it can produce the indisputable collapse achievements of the common monetary policy.

\section{NEW WAVE OF ECONOMIC POLICY COORDINATION: NEW ECONOMIC GOVERNANCE}

The rigidity of the norms of the Treaties and complicated audit process can slow the pace of economic policy coordination. Subjects of economic policy can adopt legal norms validity clause with the termination period to prevent difficulties that can arise from different interests. ${ }^{23}$ This legislation does not constitute a qualitative novelty in EU law, as was once the Paris agreement establishing the European communities for coal and steel was concluded for fifty years. Sunset clauses allow abrogation of regulations that are outdated from the legal system unless it reaches their express or tacit extension. The Commission in 2013 presented a plan for the simplification of the legislative process, which is based on the use of the said clause to remove amortisation of regulations and easier adaption to emerging economic circumstances. Such clauses in the field of monetary rights and EU economic policy can facilitate the adoption of much-needed agreement in the moments of crisis, deleting obsolete solutions listed.

The problems observed in the European Union law in the conditions of global economic and financial crisis imposes the need to reform the institutional framework of governance in EMU. Institutional structures of the new economic governance

23 Oosterwijk, J. W., Subsidiarity and Economic Policy, in: Gelauff, G.; Grilo, I.; Arjan, L. (eds.) Subsidiarity and Economic Reform in Europe, Springer, 2008, pp. 59-64 
were created outside the scope of primary law and acts of secondary legislation and shaped by the provisions of the European semester, the Agreement on the constitution of the European Stability Mechanism and the Treaty on Stabilization, Management and Coordination in EMU. ${ }^{24}$ This is complementary with the new tasks of ECB in implementation of forward guidance and nonstandard monetary policy measures in preventing future market risks ${ }^{25}$ The global debt crisis has exposed the weaknesses of the entire "international financial architecture" as a loathsome concept for the application of financial standards to avoid the effects of large-scale recession (elimination of systemic risk) and the constitution of the special body in national legislation designed to encourage compliance with these standards. ${ }^{26}$ The setting at which for preserving the stability of the euro is enough to provide the general conditions for the coordination of economic policies proved to be insufficient. The failure in the area of coordination, the EU has tried to amend certain legal precedents which provided financial assistance to Greece, Portugal and Ireland in 2010, which directly violated the provisions of primary law which explicitly prohibits collective public debt financing. Although such acts were justified by preserving monetary stability, legal consequences cannot be ignored. The first significant step towards the establishment of new institutional mechanisms, representing the Commission Report issued after negotiations with the Parliament, the European Council, the Council, the European Central Bank, the Economic and Social Committee and the Committee of the Regions, which strengthens the process of coordination. ${ }^{27}$ Concrete measures which should be taken to make the process of coordination in line with the economic goals of the founding documents include the reform of the Stability and Growth and deepened coordination of fiscal policy, control of macroeconomic disturbances and the development of competitiveness, the establishment of the European semester and management for the exit of the crisis. ${ }^{28}$ Timely identification of the causes and forms of macroeco-

24 Burger, C. et al., Governance of EU Coordination, in: Visions for Economic Policy Coordination in Europe, Vienna Federal Ministry of Economy, Family and Youth, 2013, pp. 108-117

25 Conti-Brown, P.; Lastra, M. R., Research Handbook on Central Banking, Edward Elgar Publishing, London, 2018, pp. 187-188

26 Giovanoli, M., The International Monetary Law: Issues for the New Millenium, Oxford University Press, 2001, pp. 2-3

27 Communication from the Commission to the European Parliament, the European Council, The Council, the European Central Bank, the Economic and Social Committee and the Committee of the Regions: Reinforcing Economic Policy Coordination, COM (2010) 250 final

28 The central place in the reform takes strengthens the preventive part of the Pact and verification functions of fiscal rules. In connection with the preparation and submission of convergence and stability programmes, the Commission has proposed amendment of secondary law to establish a legal basis for taking the interest of the deposit by States which did not lead adequately its fiscal policy (which would have been returned when the "correct" coordination). In managing of fiscal policy special attention 
nomic disorders is the primary condition for the effective action of the subject of economic policy. For this reason, it is necessary to incorporate the methods into existing fine pressure control mechanisms based on Art. 136. of the Treaty on the Functioning of the EU. It is required to develop quantitative indicators based on which will facilitate their control in case of crossing the critical values and the formulation of specific guidelines to the Member States which are the most affected by the consequences of the crisis. An important step in establishing a new system of economic governance represents the Commission's proposal on the definition of clear and credible rules of procedures which the Union and the Member States should start in the case of the crisis. Bankruptcy that some members of the EMU suffered confirms the need for such rules which preserve macroeconomic stability and prevent the occurrence of the effects of moral hazard. It is interesting that in this Report, the Commission for the first time expressed the opinion on the admissibility of financial support to countries in times of crisis under the condition that it is necessary for the survival of EMU. It is this attitude of the Commission on "bypassing" art.125 of the founding act in extraordinary circumstances, later became the subject of controversial actions of the European Court of Justice in the case of European Stability Mechanism. On the new architecture of EMU, we can speak in material and formal terms. ${ }^{29}$ Material dimension encompasses actions taken to provide financial support to members of the Euro-zone and the measures taken in the field of supervision of national budgetary policies. Formal dimension includes measures which are incurred as a result of the adjustments and acting the norms of primary law and secondary legislation. The material aspect of the new management concept is embodied in "a secular triptych in which the first two wings aimed at supporting the Member States, while the third wing connects the first two specific current and future incentives." Material aspects are determined with the provisions of the Agreement on the European Stability Mechanism and with the Fiscal Agreement, while the formal aspects of the regulated set of legislative measures as part of Six Pack and Package two. In practice, the formal dimension intersects the material dimension of the new architecture of EMU what is quite expected.

should be paid to the use of funds of the EU budget and cohesion policy to help the country to be able to overcome the weakness of structural policy and other challenges

29 Craig, P., Economic Governance and the Euro Crisis: Constitutional Architecture and Constitutional Implications, in: Adams, M. et al. (eds.), The Constitutionalization of European Budgetary Constraints, Oxford Hart Publishing, 2014, pp. 1-45 


\section{THE INFLUENCE OF EUROPEAN UNION ECONOMIC POLICY COORDINATION MECHANISMS ON SERBIAN ECONOMIC POLICY}

On Serbia's road to joining the European Union, the harmonisation of domestic legislation with the acquis communutaire receives a special character. While it is clearly understood for monetary law scholars that monetary regimes must be effective, the fact is that the concept of efficiency today still remains a little bit abstract, as it is primarily determined by the mechanics of designing legal solutions, which include a careful selection of doctrinal and legal concepts, form, language, style, and "luck" in regaining the right of certain views ${ }^{30}$ An optimal programme of longterm economic policy is possible only with the determination of the essential elements of coordination mechanisms of communitarian economic policy. Based on the survey results can be seen at certain recommendations de lege ferenda, which the national economic policymakers should comply it to achieve a higher level of consistency of the constituent elements and different segments of economic policy.

In the first place, a precondition for successful harmonisation of the national economic system with the provisions of the acquis communautaire is formulating of consistent, realistic, transparent, quantified programme, as stabilisation, and economic development policy. In this regard, it is important that the government completely takes responsibility for the implementation of stated objectives from the concept of economic policy during its mandate. In the case of its insufficient successful realisation, that means the application of sanctions in the form of mandate termination and new elections. Thus strict penalties are necessary because the question of European integration requires the full commitment of the main subjects of economic policy or the government, parliament, central bank and establishing their coherent cooperation with other entities. It is necessary to cooperate with trade unions and chambers of commerce, companies in the public sector and various associations of citizens such as associations of taxpayers, associations for the protection of the environment, consumer associations and the others.

If the concept of domestic economic policy does not meet all of these mentioned requirements and does not enjoy the confidence of citizens, the process of coordination will remain a dead letter, which loses on its justification and expediency. Serious intentions towards economic recovery and progress, local entities have shown by adopting the Fiscal Strategy for 2015 with two-year projections, which is mostly in line with the objectives of general guidelines for coordination.

30 Mousmoti, M., Designing Effective Legislation, Edward Elgar, London, 2019, pp. 18-19 
Thus, in the framework of the objectives and economic policy guidelines insist on achieving macroeconomic stability by implementing fiscal consolidation and elimination of obstacles to the growth of economic competitiveness of the comprehensive structural reforms. However, taking into account the failures in the implementation of the objectives of the previous fiscal strategy, the implementation of the established measures and instruments becomes imperative that the strategy itself does not become a tabula rasa. After formulating the concept of effective economic policy can be taken the steps on the harmonisation of monetary-credit and fiscal policy as well as its two most important subsystems. In the sphere of monetary policy, successful monetary integration requires to fulfil legal and economic system of convergence established by the Treaty of Maastricht and the Stability and Growth Pact. How monetary policy at European Union level fully centralised, the subjects of economic policy must make the necessary modifications in the field of monetary law that will facilitate future accession to EMU. That requires a change of normative regulation of the applicable exchange rate regime from a managed flexible exchange rate regime must be transformed into euroisation. Operationalization of such a goal may be associated with numerous difficulties, which are reflected in the fact that the introduction of the euro as the official currency, the central bank loses the ability to use the instruments of foreign exchange policy in limiting the consequences of annulling the economic and financial crisis. On the other hand, a domestic economic policy that could achieve the benefits of which are reflected in deeper and energetic market integration and in reducing transaction costs after accession to EMU. The realisation of these conditions open dilemmas that were present during the accession of all Member States to the single currency area, where the decision on selection is always determined by the establishment of a specific trade (off), i.e. sharing of costs for benefits. Taking into account the possibility of accession to the EU single market and all the advantages it brings, local subjects of economic policy should respect the experiences of other member countries and follow their path of monetary integration.

In the area of fiscal policy can be noted the existence of legislative solutions that are created based on those that exist in communitarian law. As the harmonisation of national fiscal policy cannot be imagined without the introduction of fiscal rules, it is noted that this requirement has already been met formally in the field of domestic economic policy. The fiscal rules introduced by the Law on Budget System (2015) and related to the regulation of the amount of the budget deficit and clear the debt to achieve fiscal responsibility and fiscal discipline of the government. The reference values of fiscal rules are close to those of the convergence criteria required in the EU, which confirms that the rules in the content are quite well set. Problem with the poor implementation of the fiscal rule requires that 
domestic economic policy entities determine the sanctions for non-compliance in a higher amount, should not be that way to reduce the probability of their violation. If more violations of the same rule to come, they must create the conditions for real implementation of already imposed the sanctions. An important role in the process of approaching solutions in domestic fiscal policy could potentially carry out the national courts and special state bodies that are dealing with the issue of execution and control of budgetary funds spending. The role of national courts to assess compliance with the fiscal rules is conditional on the existence of professional knowledge and skills that do not currently exist in the domestic judicial system but does not mean that efforts to institutionalise of such jurisdiction should not continue. A positive example in this aspect presents a notice legislator in the formation of the specialised court departments that will deal with the issue of financial crime, which indirectly may achieve the influence on the overall tightening of fiscal discipline. The big drawback in domestic law is the lack of specialised courts of the audit, to deal with the issue of accountability accountants and commanders for disposal and spending the budgetary funds. Pendant to such control represents the jurisdiction of the State Audit Institutions (State Auditor), which initiates the procedure for determining responsibility for spending funds and publicises the results of supervision.

The main problem is that in most initiated cases have been no clear determination of responsibility for the spending of budgetary funds, as well as the unspecified legal effect of its opinions, recommendations and guidelines about compulsory treatment. In the field of tax policy as an important segment of fiscal policy, local entities much respect the experiences of member states in the field of harmonisation of indirect taxes provided that special attention should be paid to the use of tax incentives to attract foreign investments, incentives for employment and for environmental protection, which the Member States of the European Union practice to attain the objectives of the Europe 2020 strategy aimed at a stable, sustainable and inclusive growth. When it comes to public debt management policy, economic policy actors have established the principle of non-soft budgeting in Law on the National Bank of Serbia (2015), where article 44 explicitly prohibit all forms of debt monetisation or loans to the government (covering the budget deficit). Considering that all EU Member States before the outbreak of the global financial crisis had trouble in maintaining the stability of public debt, the task of domestic subjects of economic policy in this field is the most complex. It demands solutions that have established with the new measures of economic management in the Euro-zone such as introduction of the debt-brakes and "golden rule" budget. 
Taking into account and the fact that Serbia as the successor of the former state has inherited the largest part of public debt must be taken constructive measures to reduce its height to 60\% of GDP per Law on Public Debt (2011). The main measures on this path must be taken not only may include austerity plan set forth by the current economic recovery but require an increase in the volume and structure of production and inflow of foreign investments, as a precondition for economic growth and development. That can be achieved by the application of certain incentives for the foreign capital investment in underdeveloped areas (thereby realising the objectives of regional development policy). At the same time that should not be discriminated against local businessmen giving the disproportionate privilege of foreign business companies. When it comes to structural policy in the market segment earnings, notes the serious lack of constructive use of macroeconomic dialogue, which must be corrected in the shortest possible time. That is particularly evident in the area of labour and employment policy, where the need to create conditions for strengthening trust between the representatives of trade unions, chambers of commerce and the state after collective labour agreements. How are the guidelines of the Economic Council on the coordination of economic policies except for the sustainable macroeconomic policies and keeping healthy finances, special attention is given to the investment in human capital, local entities must provide the conditions for lifelong learning and training of workers? In particular, it must fulfil the conditions for reducing the overall rates of unemployment (particular rates of young people unemployment). That requires solutions established by the Lisbon strategy and launching initiatives that have been implemented by all EU member states. As domestic economic policy has not spared the functioning of modern factors of coordination which are no longer linked only to the problem of spillover effects and the resolution of the issue of free users but also include climate change and the challenge of an ageing population, harmonisation is necessary not only in the field of monetary and fiscal policy but and in the sphere of social policy, environmental policy and policy of technical-technological and scientific development. The high degree of compliance has been achieved in the field of environmental policy, where the existing legal regimentation includes the latest solutions to European laws in terms of environmental protection. Still, there is a severe deficiency in their application, failure to act distorting the decisions of citizens due to the lack of sanctions or their inadequate level. The objectives of the European semester which relate to the creation of a society based on knowledge and require the use of tax incentives for production, products and technological innovation in a broader range. The success of the harmonisation of national solutions with European standards is conditioned and with the time-delay of the action of economic policy, which must be reduced to a level that is economically and socially acceptable. 


\section{CONCLUSION}

The conclusion is that before the national economic policymakers on the path of European integration continues to face significant challenges that even although complex to solve, they are not invincible and if between competent state institutions and citizens' associations establish a credible relationship with clearly defined responsibilities to achieve economic and legal advantages that EU membership brings. Although the process of economic integration requires and limitation of some components of the monetary, fiscal and financial sovereignty, this should not mean that the country is on the path of European integration entirely subordinate national interests to supranational demands, taking into account the recent experience of Member States during the debt crisis and the failure to maintain stability eurozone. The convergence of national economic policies with the values specified with the general and specific coordination mechanisms, cannot take the form of sui generis, because the same route had to go all the smaller Member States of the Union, leaving aside the experience of leading countries such as France and Germany in the field of coordination of fiscal policies. That does not mean that the domestic path needs ultimately to be deprived of respecting and protecting the national interests and values. We believe that local economic policymakers on the way of economic and monetary integration enjoying, conditionally speaking, a certain "qualitative advantages" that other members did not have, and are reflected in the possibility of a comprehensive and critical analysis of the results of many decades of the process of coordination of economic policy (starting from the foundation of the European economic integration through the establishment of EMU to considering the idea of introducing the concept of banking and fiscal union), whereby learning from others' mistakes and best practices selection process of harmonization of economic systems can be implemented in a way that is not only economically efficient and effective but legitimate and legally and politically justified.

\section{REFERENCES}

\section{BOOKS AND ARTICLES}

1. Aarle V. B.; Weierstrass, K.; Schoors, K., Economic Spillovers, Structural Reforms and Policy Coordination in the Euro Area, Springer, 2006

2. Amtenbrink, F.; Hermann, C., The Law of EU Economic and Monetary Union, Oxford University Press, 2020

3. Begg, I.; Hodson, D.; Maher, I., Economic Policy Coordination In the European Union, National Institute Economic Review, no. 183, 2003, pp. 66-77

4. Burger, C. et al., Governance of EU Coordination, in: Visions for Economic Policy Coordination in Europe, Vienna Federal Ministry of Economy, Family and Youth, 2013, pp. 108-117

5. Collignon, S., Economic Policy Coordination in EMU: Institutional and Political Requirements, Harvard University Center for European Studies, 2001 
6. Conti-Brown, P.; Lastra, M. R., Research Handbook on Central Banking, Edward Elgar Publishing, London, 2018

7. Cooper, I., The Subsidiarity Early Mechanism: Make it Work, Intereconomics, vol. 45, no. 5, 2006, pp. 254-257

8. Craig, P., Economic Governance and the Euro Crisis: Constitutional Architecture and Constitutional Implications, in: Adams, M. et al. (eds.), The Constitutionalization of European Budgetary Constraints, Oxford Hart Publishing, 2014

9. Feldstein, M., Coordination in the European Union, Working Paper No 18672, The National Bureau of Economic Research, 2013, pp. 1-10

10. Giovanoli, M, The International Monetary Law: Issues for the New Millenium, Oxford University Press, 2001

11. Henke, K. D., Managing Subsidiarity from an Economic Point of View, Soft Co-ordination and Hard Rules in European Economic Policy, Technische Universitat Berlin, Discussion Paper No. 2., 2006

12. Lastra, M. R., et al., European Economic and Monetary Union: History, Trends and Prospects, Year Book of European Law, 2013

13. Michael, C. W., The Political Economy of Policy Coordination-International Adjustments Since 1945, Cornell University Press, 1995

14. Mooslechner, P.; Schuerz, M., International Macroeconomic Policy Coordination: Any Lessons from EMU?, A Celective Survey on Literature, in: Hughes A., et al. (eds.), Challenges for Economic Policy Coordination within the European Monetary Union, Kluwer Academic Publisher, 2011

15. Mousmoti, M., Designing Effective Legislation, London Edward Elgar, 2019

16. Oosterwijk, J. W., Subsidiarity and Economic Policy, in: Gelauff, G,; Grilo, I.; Arjan, L. (eds.), Subsidiarity and Economic Reform in Europe, Springer, 2008

17. Pelkmans, J., An EU Subsidiarity Test is Indispensable, Intereconomics, vol. 41, no. 5, 2006, pp. 254-257

18. Prokopijević, M., The Euroepan Union-Introduction, Belgrade, 2009

19. Schäfer, W., Harmonization and Centralization Versus Subsidiarity: Which Should Apply Where?, Intereconomics, vol. 45, no. 1, 2006, pp. 246-249

20. Schiede, J., Macroeconomic Policy Coordination in Europe-An Agnostic View, Kiel Institute for World Economics, Kiel Working Papers, No. 1174, 2003

21. Vukadin, E., Economic Policy, Belgrade, 2009

22. Wyplosz, C.; Baldwin, Richard, Economics of European Integration, McGraw-Hill Higher Education, 2012

\section{EU LAW}

1. Communication from the Commission to the European Parliament, the European Council, The Council, the European Central Bank, the Economic and Social Committee and the Committee of the Regions: Reinforcing Economic Policy Coordination, COM (2010) 250 final

2. European Central Bank, The ECB's Relation with Institutions and Bodies of the European Community, Monthly Bulletin, 2004 